\title{
Intelligent irrigation performance: evaluation and quantifying its ability for conserving water in arid region
}

\author{
Hussein M. Al-Ghobari • Fawzi S. Mohammad
}

Received: 19 January 2011/Accepted: 1 October 2011/Published online: 27 October 2011

(C) The Author(s) 2011. This article is published with open access at Springerlink.com

\begin{abstract}
Intelligent irrigation technologies have been developed in recent years to apply irrigation to turf and landscape plants. These technologies are an evapotranspiration (ET)-based irrigation controller, which calculates ET for local microclimate. Then, the controller creates a program for loading and communicating automatically with drip or sprinkler system controllers. The main objective of this study was to evaluate the effectiveness of the new ET sensors in ability to irrigate agricultural crops and to conserve water use for crop in arid climatic conditions. This paper presents the case for water conservation using intelligent irrigation system (IIS) application technology. The IIS for automating irrigation scheduling was implemented and tested with sprinkle and drip irrigation systems to irrigate wheat and tomato crops. Another irrigation scheduling system was also installed and operated as another treatment, which is based on weather data that retrieved from an automatic weather station. This irrigation control system was running in parallel to the former system (IIS) to be control experiments for comparison purposes. However, this article discusses the implementation of IIS, its installation, testing and calibration of various components. The experiments conducted for one growing season 2009-2010 and the results were represented and discussed herein. Data from all plots were analyzed, which were
\end{abstract}

Mention of trade names was for informational purposes only and does not constitute endorsement by the authors or by the institutions they serve.

H. M. Al-Ghobari $(\varangle)$ · F. S. Mohammad

Agricultural Engineering Department,

College of Food and Agriculture sciences,

King Saud University, P.O. Box 2460,

Riyadh 11451, Saudi Arabia

e-mail: hghobari@ksu.edu.sa including soil water status, water consumption, and crop yield. The initial results indicate that up to $25 \%$ water saving by intelligent irrigation compared to control method, while maintaining competing yield. Results show that the crop evapotranspiration values for control experiments were higher than that of ET-System in consistent trend during whole growth season. The analysis points out that the values of the two treatments were somewhat close to each other's only in the initial development stages. Generally, the ET-System, with some modification was precise in controlling irrigation water and has been proven to be a good mean to determine the water requirements for crops and to schedule irrigation automatically.

Keywords Intelligent irrigation - Evapotranspiration . Smart system $\cdot$ Control irrigation $\cdot$ Arid region

\section{Introduction}

There were many intelligent irrigation systems (IISs) available and were used to compute crop water requirements based on climatic data. Usually, intelligent irrigation was integrated with smart controllers and using microclimatic data to schedule irrigation water. The irrigation controller functions were to govern the solenoid valves (control action) in irrigation process. Ultimately, the controller decides when to start and how long to irrigate, in order to bring the controlled variable up to the desired value (set-point).

Intelligent or smart irrigation technologies were regarded as a promising tool to achieve landscape water savings and reduce non-point source pollution (Nautiyal et al. 2010). Currently, there were a number of intelligent irrigation systems that can operate without human 
intervention. The smart controllers integrate many disciplines to produce a significant improvement in crop production and resource management (Norum and Adhikari 2009). Application of smart irrigation controllers in an automated irrigation system has become a new trend in turf industry. There were numerous smart irrigation control manufacturers, which already exist or were emerging in the marketplace. A recent study was conducted in Cary, North Carolina to evaluate the effectiveness of two smart systems (Nautiyal et al. 2010).

The Kingdom of Saudi Arabian intelligent irrigation technology became recently an essential and important for irrigation water scheduling. Hence, there is an increase in agricultural production and a need to secure food to meet the increasing population. Improving irrigation efficiency can contribute greatly to reducing production of cost of crops, making the agriculture more competitive and sustainable. Definitely, the widespread adoption of intelligent irrigation would conserve a significant portion of excess water applied.

Most of problems facing irrigation practices were solved by adopting intelligent irrigation controllers (Colin and Whitford 1996; Capraro et al. 2008). This novel control method uses different mathematical models and measures the error between the steady-state-sensed value and the desired value. If error exceeds some given tolerances, then the controller uses an adaptive algorithm that modifies model and control parameters (Iserman et al. 1992). Most of the systems were using computers as central control unit, which were capable of transferring accurate data automatically and remotely or through telephone in real time. Recent technological advances have made soil water sensors available for efficient and automatic operation of irrigation systems.

The controller generally was connected to an electrical circuit that operates a solenoid attached to each valve. Several moisture sensors were commercially available used in sensing soil water (Muñoz-Carpena et al. 2003). They generally can be used for manual readings to guide irrigation scheduling, while some of them can also be interfaced directly with the irrigation controller in a closed loop control system to automatically irrigate the crop (Zazueta et al., 1994).

The new IIS was currently under evaluation at the trial farm in Dookie, Egypt and initial results indicate up to $43 \%$ (average 38\%) water saving over conventional irrigation control methodologies (Dassanayake et al. 2009). In the past 10 years, smart irrigation controllers have been developed by a number of manufacturers and have been promoted by water purveyors in an attempt to reduce overirrigation (Michael and Dukes 2008).There were many intelligent irrigation systems computing applied water and ET that based on climatic conditions (McCready et al.
2009; Muñoz-Carpena and Dukes 2005; Lozano and Mateos 2007).These systems differ in their accuracy and reliability.

Playán and Mateos (2006) and Wolter and Burt (1996) discussed how the modernization and optimization of irrigation systems can contribute to the increase of water productivity in a context of global water scarcity. This process may be set up in two ways: (i) open-loop or, (ii) closed-loop (Kuo 1995). Automation of irrigation systems, based on soil moisture sensing (SMS) has the potential to provide maximum water-use efficiency (WUE). Such systems are maintaining soil moisture between a desired range, optimal or adequate, for plant growth and/or quality (Muñoz-Carpena and Dukes 2005).

Intelligent irrigation usually depends on systems utilizing modern electronic sensors, which were capable of collecting data, analyzing and decision making to start/stop irrigation. These devices were transmitting the decisions to electronic controller devices, which control sprinkler or drip irrigation system. Several moisture sensors were commercially available, such as tensiometers. Some researchers used tensiometers sensors in irrigation scheduling for tomato under drip irrigation system (Mendez-Barroso et al. 2008; Smajstrla and Locascio 1997). They found that the tomato crop during 4 years had a water tension equal to $10 \mathrm{cb}$.

The objective of this article was to evaluate the use intelligent system with sprinkle and drip irrigation systems and field crops with different scheduling techniques in arid region, such as Saudi Arabia.

\section{Materials and methods}

Site location and equipment installations

The experiments involved selection of the appropriate fields for implementing and conducting the necessary experiments. This study was performed at the experimental farm of the College of Food and Agriculture Sciences, King Saud University, Riyadh. Initially, the necessary hardware were selected such as two IIS units, automatic weather station, enviroscan, tensiometers, Water Marks, electronic controllers, solenoid valves, water meters, pumps, and pressure gauges. While other accessories are made available, such as polyethylene and PVC pipes, elbows, tee joints, short nipples, ball valves, gate valves, adapters, couplings, line filters, sprinklers, and emitters. The field was divided into four plots and the layout for two types of irrigation systems were shown in Figs. 1 and 2).

The weather station was installed and set in a location identical to the conditions of World Meteorological Organization (WMO). This weather station was used to measure 


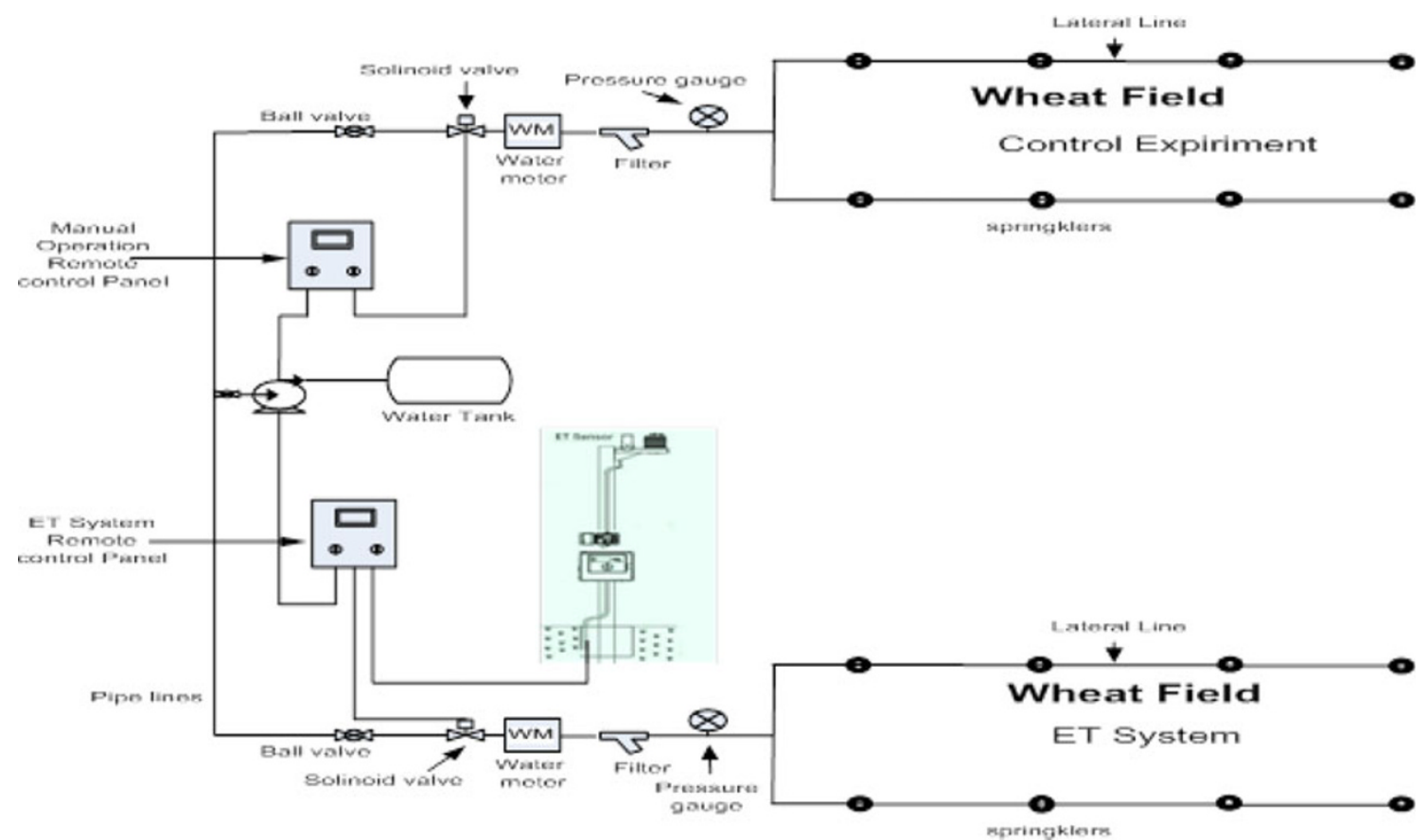

Fig. 1 Schematic diagram of wheat field using sprinkler irrigation system for IIS and ICS treatments

the climate parameters that were used to compute evapotranspiration $\left(\mathrm{ET}_{\mathrm{o}}\right)$. These values were then compared with those obtained from the IIS in both fields of wheat and tomato crops. These devices were programmed in situ, taking into account the type of crops and the environment prevailing conditions in the area. Then, they were calibrated and configured to implement the next phase of the study before collecting real data.

Devices of the two IIS used were installed according to manufacturer's instructions in the field of planned experiments. The systems were installed in the two different plots, for controlling irrigation for wheat and tomato crops. Adjacent to these plots, automatic meteorological stations were installed.

Intelligent system components, functions, and installation

The intelligent irrigation system used in the study was Hunter ET-System*, the terms used in this text interchangeably, was chosen for this study. This system cannot be considered as the best system, but it was cheaper and available in the local market. Moreover, it can be customized by station (or "zone") for specific plant, soil, and sprinkler types. This type of system uses digital electronic controllers, ET sensors, and module. Its platform wired to ET module, which senses local climatic condition via different sensors measuring air wind speed, rainfall, solar radiation, air temperature, and relative humidity. Then the ET module receives the data from the ET sensor, and applies it to the individual fields (zones) of irrigation. The IIS calculates crop evapotranspiration $\left(\mathrm{ET}_{\mathrm{c}}\right)$ for local microclimate automatically based on modified Penman equation (Allen et al. 1998) and creates a scientific program and downloads to the controller. The ET module was plugged into the irrigation controller Pro $\mathrm{C}$, which was called Controller Intelligent Port and adjusts irrigation run times to only replace the amount of water the plants have lost, at a rate at which soil can absorb it. Irrigation controller Pro $\mathrm{C}$ was an irrigation controller that can control valves and pumps.

Intelligent Irrigation System requires a complete database for each station (or "zone") to be controlled. To setup this database was easy, but the operator was completely responsible for the accuracy of the information and obtained results from using the database. Every system must be carefully observed after initial installation. Generally, most systems require adjustment, at station level, for some time after installation to provide ideal results. Inattention can result in plant damage and water waste. However, to achieve this study, two IIS were installed in the fields and used to irrigate two different crops by two irrigation methods; wheat and tomato crops under sprinkle and drip irrigation systems (Figs. 1, 2).

Irrigation systems installation

The site of the study was divided into two main fields, each divided into two plots. One field was allocated for wheat crop and the other for tomato crop, and each field

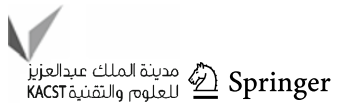




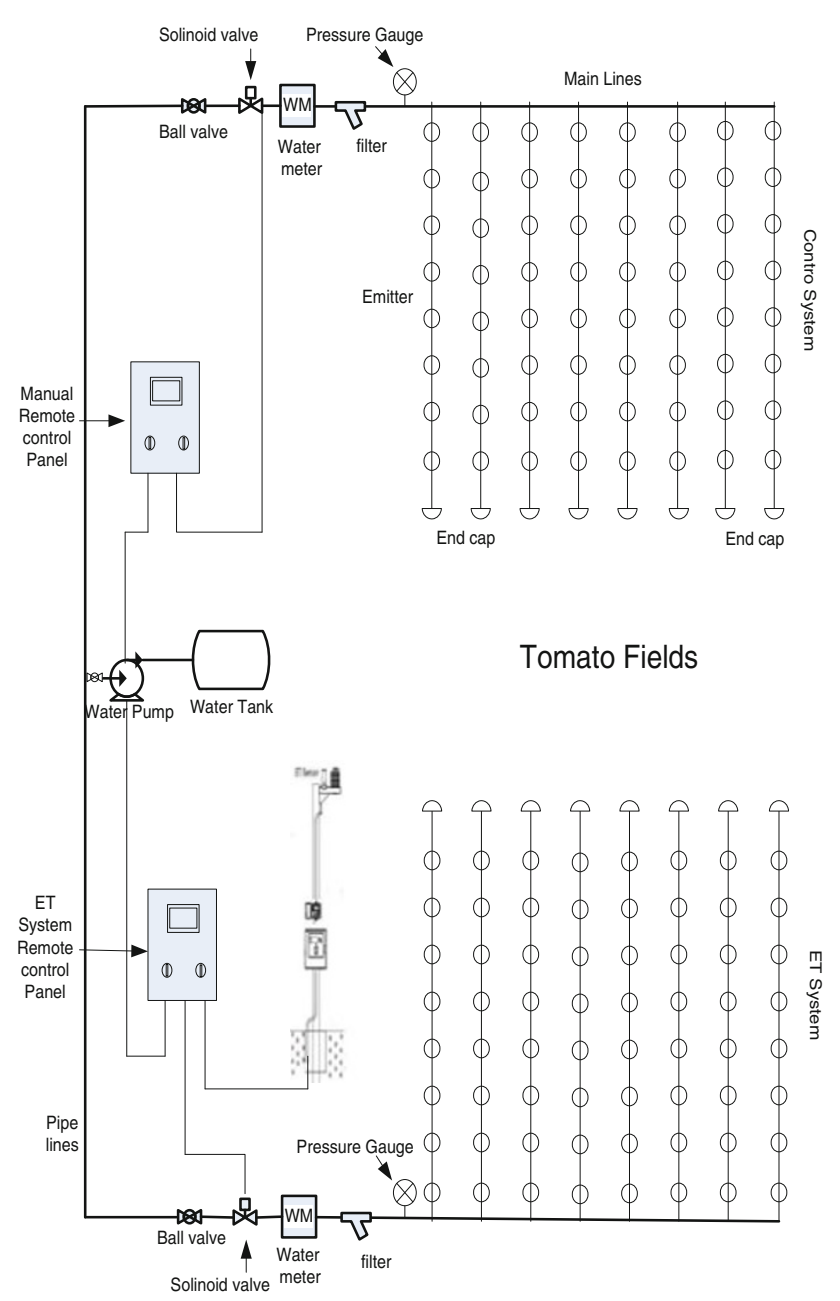

Fig. 2 Schematic diagram of tomato field using drip irrigation systems for both intelligent irrigation (IIS) and control (ICS) systems

consisting of two plots IIS and irrigation control system (ICS), as shown in Figs. 1 and 2. In IIS plots, crops were irrigated automatically via the Hunter ET System*, and in ICS plots irrigation scheduling was done manually by using the weather station, which was installed at the site and $\mathrm{ET}_{\mathrm{c}}$ values. Solid sprinkler and drip irrigation systems were installed for both fields (Figs. 1, 2). These irrigation systems were designed to achieve high performance and distributed water uniformity throughout irrigation. Each system was equipped with controllers to control the pressure and flow meter to quantify the water added in each irrigation event.

Sprinkler systems were used for wheat crops, while drip irrigation systems were used to irrigate tomato crops. The sprinkler and drip systems were evaluated in the fields according to the methodology of Merriam and Kelle (1978) and ASABE Standard, S436.1 (2007). Evaluation tests were conducted for each irrigation system by checking values of the performance indexes under operating field conditions. All indices values were found to be within acceptable results and with good water distribution uniformity.

\section{Crops planting and monitoring}

Wheat (YecoraRojo) was planted in two plots on 9 December 2009 and each plot was equal to an area of $9 \mathrm{~m} \times 24 \mathrm{~m}$. They were harvested on 25 April 2010. Each plot was irrigated by sprinkler irrigation system, and the irrigation scheduling for the crop during the season were controlled by IIS for one plot, while the other was irrigated by ICS as shown in (Fig. 1). The sowing rate was $180 \mathrm{~kg} /$ ha and fertilizers were added for both wheat plots. Fertilizers were containing nitrogen, phosphorus, potassium elements, and other elements were applied at the rate of $100 \mathrm{~kg} / \mathrm{ha}$. The other two plots were cultivated with tomato (Lycopersicon esculentum Mill, GS-12) and transplanted into the field on 14 February 2010. The last irrigation was in 29 May 2010. Each plot was irrigated by drip irrigation system. The irrigation scheduling was controlled by IIS and ICS. The area of each tomato plot was $10 \mathrm{~m} \times 12.5 \mathrm{~m}$, and located close to the wheat plots. Tomato seed germination was in the cubes Jiffy-7 in greenhouse and seedlings were transplanted in the field and irrigated lightly. Phosphate and potassium fertilizers were added for tomato followed by fungal and viral diseases programs.

At wheat maturity, measurements were made on grain yield (GY), biological yield (BY), plant height (PH). Grain and biological yields were determined from the 5 rows $\times 1 \mathrm{~m}$. Harvest index (HI) was calculated as grain yield/biological yield. Grain yield was estimated as the weight of clean grain (taken from random seven samples with $1 \mathrm{~m}^{2}$ and converted to grain yield per hectare). Moreover, 1,000 grain weight was recorded as the average of samples taken at random from the harvested plants of each treatment. Plant height was measured at maturity as the distance from soil surface to the top of the main spike, excluding the awns. Daily and weekly $\left(\mathrm{ET}_{\mathrm{c}}\right)$ rates during the growth period were determined for IIS and ICS treatments. Irrigation water depths $\left(D_{\mathrm{g}}\right)$ and accumulative depths added to wheat crop via IIS and ICS plots were monitored throughout the growing season.

Similarly, daily $\mathrm{ET}_{\mathrm{c}}$ rates for tomato were measured by IIS and ICS systems. The actual irrigation water depths $\left(D_{\mathrm{g}}\right)$ added to tomato crop by both systems were monitored and recorded by flow meters. Data on the quantities of irrigation water, plant growth and productivity were gathered daily in special forms prepared for this purpose. During the growing season, the data at first hand were analyzed. 
Sensors and controllers used

Soil water content (SWC) must be accurately observed for irrigation decision support. Moisture content was measured by the volumetric method at a depth of $20,40,60 \mathrm{~cm}$ from the soil surface, which was used for calibration purposes. In this method, soil samples were taken from all plots once each week and analyzed in the Irrigation Laboratory. In light of these results, all the soil moisture measuring instruments used in this study were calibrate. Special forms were prepared to fill the data and results of this method.

In addition, three sensors were used in this study to measure soil-water potentials: i.e. Watermarks, Tensiometers, and Enviroscan. Three groups of tensiometers were installed in three plots of sandy loam soil at depths of 20, 40, $60 \mathrm{~cm}$ from the soil surface. Another three Watermark sensors were installed in the same plot at the same depths. Enviroscan was also installed in one location at five different depths $10,20,30,40,50 \mathrm{~cm}$. Hence, it was continuous soil moisture monitoring sensor and the world's leading irrigation monitoring and scheduling device. It was therefore considered as a modern device capable of measuring soil moisture content continuously and transferring data through internet in the form of reports or graphs.

A set of soil moisture content measurements by the three methods were taken from IIS and ICS plots. The volumetric SWC data determined from the samples were regressed against the tensiometers and watermarks potential readings.

\section{Operation time required}

To calculate $\mathrm{ET}_{\mathrm{c}}$ for wheat, daily $\mathrm{ET}_{\mathrm{o}}$ values were first measured by the meteorological station and then were multiplied by crop coefficients and water application efficiency. Hence, by knowing the area of wheat plot $\left(216 \mathrm{~m}^{2}\right)$ and discharge from the eight sprinklers $\left(4.88 \mathrm{~m}^{3} / \mathrm{h}\right)$, the water quantity to be added in a specific event can be found out. Accordingly, the actual operation time required was then calculated using the following procedure.

$$
\begin{aligned}
T(\min ) & =\frac{V(\mathrm{Lit})}{Q_{\mathrm{s}}(\mathrm{Lit} / \mathrm{min})}=\frac{K_{\mathrm{c}} \times \mathrm{ET}_{\mathrm{o}}(\mathrm{mm}) \times A\left(\mathrm{~m}^{2}\right)}{\mathrm{E}_{\mathrm{a}} \times Q_{\mathrm{s}}(\mathrm{Lit} / \mathrm{min})} \\
T(\min ) & =\frac{K_{\mathrm{c}} \times \mathrm{ET}_{\mathrm{o}}(\mathrm{mm}) \times 216}{0.75 \times \frac{4.88 \times 1,000}{60}} \\
& =K_{\mathrm{c}} \times \mathrm{ET}_{\mathrm{o}}(\mathrm{mm}) \times 3.541
\end{aligned}
$$

where $T$ actual operation time required, min; $V$ water volume to be added, lit.; $Q_{\mathrm{s}}$ discharge from the irrigation system, lit/min; $K_{\mathrm{c}}$ crop coefficient; $A$ area of the field, $\mathrm{m}^{2}$; $\mathrm{ET}_{\mathrm{o}}$ reference evapotranspiration, $\mathrm{mm} ; E_{\mathrm{a}}$ water application efficiency ( $75 \%$ for sprinkler and $90 \%$ for drip irrigation).
Similarly, the values of tomato daily $\mathrm{ET}_{\mathrm{o}}$ measured by the meteorological station. These values were multiplied by crop coefficients and water application efficiency for determining crop water requirement. Hence, by knowing the area of the field $\left(125 \mathrm{~m}^{2}\right)$ and the discharge rate from the drippers $(1,220 \mathrm{l} / \mathrm{h})$, water quantity to be added in specific event could be determined. Accordingly, the actual operation time required was then calculated using the following procedure.

$$
\begin{aligned}
T(\min ) & =\frac{V(\mathrm{Lit})}{Q_{\mathrm{s}}(\mathrm{Lit} / \mathrm{min})}=\frac{K_{\mathrm{c}} \times \mathrm{ET}_{\mathrm{o}}(\mathrm{mm}) \times A\left(\mathrm{~m}^{2}\right) \times P_{\mathrm{w}}}{\mathrm{E}_{\mathrm{a}} \times(1-\mathrm{LR}) \times Q_{\mathrm{s}}(\mathrm{Lit} / \mathrm{min})} \\
T(\min ) & =\frac{K_{\mathrm{c}} \times \mathrm{ET}_{\mathrm{o}}(\mathrm{mm}) \times 125 \times 0.40}{0.90 \times(1-0.10) \times \frac{1,220}{60}} \\
& =K_{\mathrm{c}} \times \mathrm{ET}_{\mathrm{o}}(\mathrm{mm}) \times 3.04
\end{aligned}
$$

where $\mathrm{LR}=$ leaching requirement, $10 \% ; E_{\mathrm{a}}=$ water application efficiency, 90\%; $P_{\mathrm{w}}=$ wetted area percentage, $40 \%$.

When irrigation scheduling was determined for each crop in ICS plots, the irrigation system was turned on and off in control experiments manually not automatically as in IIS. The depth of irrigation water $\left(D_{\mathrm{g}}\right)$ for intelligent treatment irrigated by sprinklers was calculated from the difference flow meter readings before and after irrigation. These values were divided by the field area $\left(216 \mathrm{~m}^{2}\right)$ and multiplied by 1,000 to be converted into $\mathrm{mm}$. Similar, steps were followed in case of drip irrigation and divided the by wetted area instead of all area. However, after completing the irrigation process, the actual time required and meter readings were recorded in both cases.

\section{Results and discussions}

Soil analysis and soil-water status

The soil analysis from the experimental site shows that the dominant soil texture of the layers $(0-20,20-30$, $30-60 \mathrm{~cm}$ ) was sandy loam. The soil-water potential values for the two wheat plots were fluctuating between 10 and $70 \mathrm{KPa}$ throughout the growing season. Generally, the upper layer $(0-20 \mathrm{~cm})$ soil-moisture was ranging from 10 to $55 \mathrm{KPa}$. This was due to frequent irrigation with sufficient water and the soil was not subjected to sever stress.

The volumetric SWC determined from the three layers was regressed against the tensiometers and watermark readings. The regression equations of transforming the potential readings to volumetric water content were generated as well. The correlation $\left(R^{2}\right)$ found to be ranging from 0.96 to 0.98 and from 0.91 to 0.95 for tensiometers and water marks successively. It appears that the two sensors were less responsive to the soil drying between 
irrigations events than gravimetric method. This was because irrigation events were more frequents.

Comparison between controller types

\section{Evapotranspiration $\left(E T_{c}\right)$}

The processor in IIS determined $\mathrm{ET}_{\mathrm{o}}$ based on measured weather parameters, which were sensed by smart controllers. Furthermore, these controllers were using weather data to adjust the amount of irrigation water applied automatically. Weekly $\mathrm{ET}_{\mathrm{c}}$ rates for wheat and tomato crops under IIS experiments during growing season were calculated from daily records (Table 1 ). Then, these results were compared with the data obtained from ICS experiments.

The $\mathrm{ET}_{\mathrm{o}}$ rates for both crops in control plots were calculated utilizing weather data obtained from local station using modified Penman equation. This approach was mainly based on estimating the expected available SWC or depletion after a certain period of time. Irrigation was carried out when the estimated value of SWC dropped to a specified threshold level. Then, the required water depth was determined from the soil water balance equation. Adjustments to $\mathrm{ET}_{\mathrm{o}}$ for particular plant types were made using crop coefficients; $K_{\mathrm{c}}$ (Allen et al. 1998), where the

Table 1 Weekly $\mathrm{ET}_{\mathrm{c}}$ for wheat crop under the two treatments IIS and ICS

\begin{tabular}{lcllc}
\hline $\begin{array}{l}\text { Growth period } \\
\text { (week) }\end{array}$ & $\begin{array}{l}\mathrm{ET}_{\mathrm{c}} \text { for IIS } \\
(\mathrm{mm} / \text { day })\end{array}$ & $\begin{array}{l}\mathrm{ET}_{\mathrm{o}} \\
(\mathrm{mm} / \text { day })\end{array}$ & $K_{\mathrm{c}}$ & $\begin{array}{l}\mathrm{ET}_{\mathrm{c}} \text { for ICS } \\
(\mathrm{mm} / \text { day })\end{array}$ \\
\hline 1 & 1.71 & 2.81 & 0.70 & 1.97 \\
2 & 1.78 & 3.81 & 0.70 & 2.67 \\
3 & 2.12 & 3.34 & 0.99 & 3.13 \\
4 & 2.62 & 3.81 & 0.99 & 3.78 \\
5 & 2.79 & 4.12 & 0.99 & 4.08 \\
6 & 2.86 & 4.17 & 0.99 & 4.13 \\
7 & 2.95 & 4.25 & 0.99 & 4.20 \\
8 & 3.50 & 4.11 & 0.99 & 4.07 \\
9 & 3.62 & 4.31 & 1.10 & 4.74 \\
10 & 3.77 & 4.57 & 1.10 & 5.03 \\
11 & 4.27 & 4.80 & 1.10 & 5.28 \\
12 & 4.15 & 5.01 & 1.10 & 5.51 \\
13 & 4.36 & 5.29 & 1.10 & 5.82 \\
14 & 4.67 & 5.98 & 1.10 & 6.58 \\
15 & 5.05 & 6.09 & 1.10 & 6.70 \\
16 & 3.13 & 8.28 & 0.35 & 3.55 \\
17 & 1.96 & 6.36 & 0.35 & 2.23 \\
Avg. rate & 3.25 & & & 4.32 \\
Sum & 386.75 & & & 514.36 \\
\hline & & & & \\
\hline
\end{tabular}

crop $\mathrm{ET}_{\mathrm{c}}$ was calculated as the product of $K_{\mathrm{c}}$ and $\mathrm{ET}_{\mathrm{o}}$ for ICS experiments only.

\section{Water application for wheat}

Generally, in IIS plots for both crops the irrigation initiatedand terminated according to the data collected and processed by the intelligent system and shown on the instrument's monitor. In light of this, the operator would carry out irrigation accordingly at a convenient time. In this study, irrigation was started at early morning (7 a.m.) for both treatments. This system was used to schedule irrigation based on weather parameters measurements. In addition, readings taken from the provided sensors were recorded continuously. Automatically retrieving these data and processing calculation for determining the initiating or terminating irrigation event. While, there were some options to choose for supplying more water or less according to the needs of plants. In this project, the system was preset to operate with $80 \%$ of ET early cultivation days.

While, $\mathrm{ET}_{\mathrm{o}}$ for control plots was measured by the automatic weather station which was based on the Modified Penman Method, FAO version. Daily $\mathrm{ET}_{\mathrm{o}}$ measurements multiplied by adequate crop coefficients can accurately provide $\mathrm{ET}_{\mathrm{c}}$ and used to efficiently schedule automated micro irrigation systems. Table 1 shows the crop coefficient $\left(K_{\mathrm{c}}\right)$ for wheat to be multiplied with $\mathrm{ET}_{\mathrm{o}}$ for different stages of crop development. Based on local experience, these stages were approximately of $15,40,60$, and 20 days, respectively, and were considered for evaluation of $K_{\mathrm{c}}$. The stages were initial, crop development, mid-season, and late season.

By comparing the total $\mathrm{ET}_{\mathrm{c}}$ for wheat crops in both treatments, IIS and ICS, found that the total $\mathrm{ET}_{\mathrm{c}}$ were 386.75 and $514.36 \mathrm{~mm}$, respectively. As shown in Table 1, the accumulated $\mathrm{ET}_{\mathrm{c}}$ value from IIS was $25 \%$ less than that one obtained from the ICS. This represents a high percentage of conserving water which compensate for the reduction of productivity, especially in areas that suffer from water scarcity. The results indicated that each $1 \mathrm{~mm}$ water depth applied by IIS and ICS to the wheat crop produced 13 and $11.9 \mathrm{~kg} / \mathrm{mm}$, respectively. Therefore, conserving water was something very important in areas experiencing severe drought such as Saudi Arabia. In general, this lack of water did not affect the external appearance of the plant. From this table, it can be depicted that $\mathrm{ET}_{\mathrm{c}}$ rates for ICS were higher than those for IIS and following similar trends during whole growth season.

Weekly irrigation water $\left(D_{\mathrm{g}}\right)$ added to wheat crop for IIS and ICS treatments were calculated and tabulated in Tables 2 and 3. The total amounts of irrigation water applied during the season for wheat in the (IIS) and (ICS) 
Table 2 Weekly irrigation water added $\left(D_{\mathrm{g}}\right)$ to wheat crop for IIS treatments

\begin{tabular}{lccc}
\hline $\begin{array}{l}\text { Growth } \\
\text { period (week) }\end{array}$ & $\begin{array}{l}\text { Water } \\
\text { added }\left(\mathrm{m}^{3}\right)\end{array}$ & $\begin{array}{l}\text { Irrigation depth } \\
\left(D_{\mathrm{g}}\right)(\mathrm{mm})\end{array}$ & $\begin{array}{l}\text { Accumulative depth } \\
\left(D_{\mathrm{g}}\right) \mathrm{c}(\mathrm{mm})\end{array}$ \\
\hline 0 & & & 0 \\
1 & 4.88 & 22.59 & 22.59 \\
2 & 6.10 & 28.24 & 50.83 \\
3 & 4.55 & 21.06 & 71.90 \\
4 & 9.19 & 42.55 & 114.44 \\
5 & 2.60 & 12.04 & 126.48 \\
6 & 4.64 & 21.48 & 147.96 \\
7 & 4.55 & 21.06 & 169.03 \\
8 & 5.04 & 23.33 & 192.36 \\
9 & 6.43 & 29.77 & 222.13 \\
10 & 6.51 & 30.14 & 252.27 \\
11 & 7.56 & 35.00 & 287.27 \\
12 & 6.83 & 31.62 & 318.89 \\
13 & 6.75 & 31.25 & 350.14 \\
14 & 13.99 & 64.77 & 414.91 \\
15 & 11.39 & 52.73 & 467.64 \\
Sum & 101.01 & 467.64 & \\
\hline
\end{tabular}

Table 3 Weekly irrigation water added $\left(D_{\mathrm{g}}\right)$ to wheat crop for ICS treatments

\begin{tabular}{lccc}
\hline $\begin{array}{l}\text { Growth } \\
\text { period (week) }\end{array}$ & $\begin{array}{l}\text { Water } \\
\text { added }\left(\mathrm{m}^{3}\right)\end{array}$ & $\begin{array}{l}\text { Irrigation depth } \\
\left(D_{\mathrm{g}}\right)(\mathrm{mm})\end{array}$ & $\begin{array}{l}\text { Accumulative depth } \\
\left(D_{\mathrm{g}}\right) \mathrm{c}(\mathrm{mm})\end{array}$ \\
\hline & & & 0 \\
1 & 6.1 & 28.24 & 28.24 \\
2 & 6.83 & 31.62 & 59.86 \\
3 & 5.21 & 24.12 & 83.98 \\
4 & 8.3 & 38.43 & 122.41 \\
5 & 5.45 & 25.23 & 147.64 \\
6 & 6.34 & 29.35 & 176.99 \\
7 & 6.43 & 29.77 & 206.76 \\
8 & 6.75 & 31.25 & 238.01 \\
9 & 7.4 & 34.26 & 272.27 \\
10 & 6.9 & 31.94 & 304.21 \\
11 & 7.33 & 33.94 & 338.15 \\
12 & 7.51 & 34.77 & 372.92 \\
13 & 9.53 & 44.12 & 417.04 \\
14 & 12.83 & 59.40 & 476.44 \\
15 & 19.76 & 91.48 & 567.92 \\
Sum & 122.67 & 567.92 & \\
\hline
\end{tabular}

treatments were 467.68 and $567.87 \mathrm{~mm}\left(4,676.8 \mathrm{~m}^{3} / \mathrm{ha}\right.$ and $5,678.7 \mathrm{~m}^{3} / \mathrm{ha}$ ), respectively. These amounts were less than the amount of irrigation water practiced by the framers in the region, which was at least $6,000 \mathrm{~m}^{3} / \mathrm{ha}$. The IIS treatment gives $17.64 \%$ lesser amount than that applied for the ICS treatment.

The weekly accumulative irrigation water added $\left(D_{\mathrm{g}}\right)$ to wheat throughout crop growing period for both treatments were plotted in Fig. 3. The analysis of these two curves points out that their values were close only in the initial development stages of wheat and extremely great differences appear in the late season at full maturity of the crop.

\section{Water application for tomato}

Similarly, the irrigation for tomato crop was initiated and terminated according to the data collected and processed by the intelligent system. The convenient irrigation time for both treatments, IIS and ICS, also were at early morning. For IIS treatments, the schedule irrigation based on weather parameters measurements. In addition, readings were taken from provided sensors and recorded continuously during the season. Then, they were automatically retrieved and in determining initiating or terminating irrigation event. Configuration of the system was used to be changed to meet the needs of plants.

The $\mathrm{ET}_{\mathrm{o}}$ rates for tomato control experiment were measured by the automatic weather station similar to wheat control treatment using modified Penman Method, FAO version. Daily $\mathrm{ET}_{\mathrm{o}}$ measurements were multiplied by adequate crop coefficients to accurately provide $\mathrm{ET}_{\mathrm{c}}$ and were used to efficiently schedule automated micro irrigation systems. Table 4 shows the crop coefficient $\left(K_{\mathrm{c}}\right)$ for tomato to be multiplied by $\mathrm{ET}_{\mathrm{o}}$ for different stages of crop development to determine $\mathrm{ET}_{\mathrm{c}}$.

Weekly $\mathrm{ET}_{\mathrm{c}}$ values for tomato versus crop growth period under IIS and ICS were shown in Fig. 4. From this figure, it can be depicted that $\mathrm{ET}_{\mathrm{c}}$ rates for ICS were higher than those for IIS and following similar trends during whole growth season. The analysis of these two curves points out that their values were close only in the initial development stages. Extremely great differences appear in the 3 rd-7th weeks of season. This means that during this growing period the water application was much more in ICS treatment than IIS. This may explain that tomato plants were not exposed to water deficient nor to stress through crop growth period. From this conclusion, it can be interpreted that the IIS more appropriates to irrigate vegetables, such as tomato, coupled with drip irrigation system than for cereal crops using sprinkle irrigation under arid conditions. The reason of excesses on irrigation water applied could be due to the adopted $K_{\mathrm{c}}$ values as obtained from literature for variety region.

Weekly irrigation water $\left(D_{\mathrm{g}}\right)$ added to tomato crop for IIS and ICS treatments were calculated and tabulated in Tables 5 and 6. From these tables the total amounts of irrigation water applied during the season for tomato in the 
Fig. 3 Weekly accumulative irrigation water added $\left(D_{\mathrm{g}}\right)$ to wheat crop during the growth period for IIS and ICS treatments

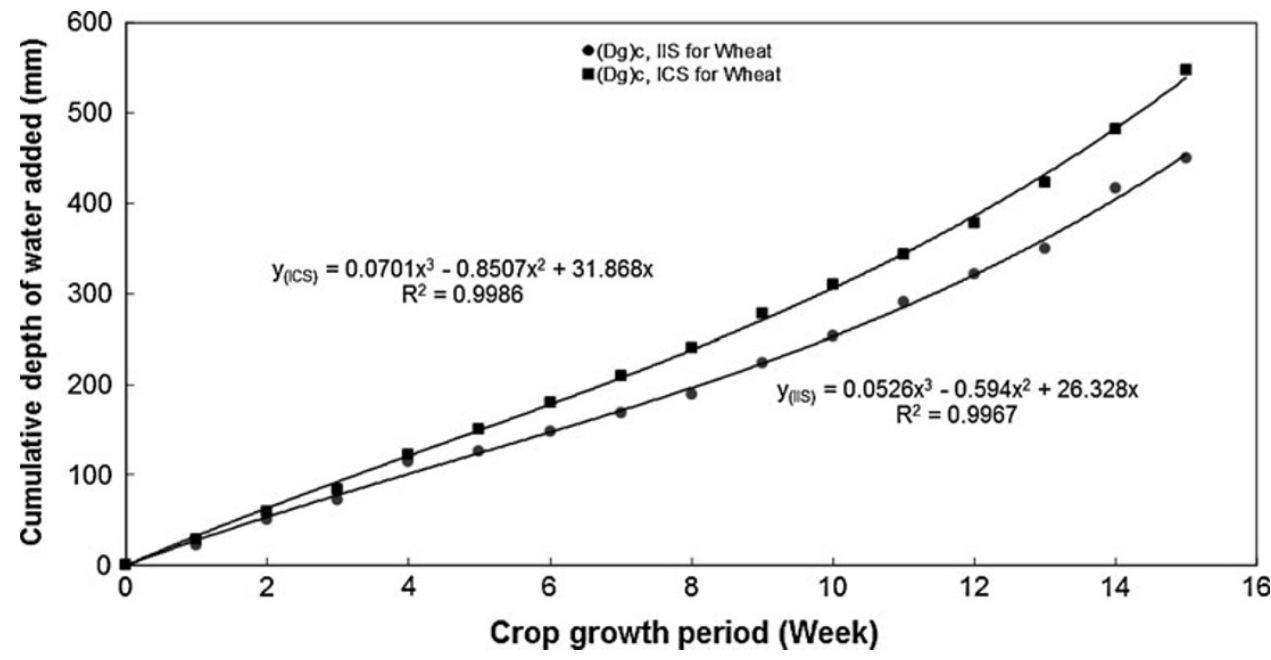

Table 4 Weekly $\mathrm{ET}_{\mathrm{c}}$ for tomato crop under the two treatments IIS and ICS

\begin{tabular}{lcllc}
\hline $\begin{array}{l}\text { Growth period } \\
\text { (week) }\end{array}$ & $\begin{array}{l}\mathrm{ET}_{\mathrm{c}} \text { for IIS } \\
(\mathrm{mm} / \text { day })\end{array}$ & $\begin{array}{l}\mathrm{ET}_{\mathrm{o}} \\
(\mathrm{mm} / \text { day })\end{array}$ & $K_{\mathrm{c}}$ & $\begin{array}{l}\mathrm{ET}_{\mathrm{c}} \text { for ICS } \\
(\mathrm{mm} / \text { day })\end{array}$ \\
\hline 1 & 2.58 & 4.80 & 0.70 & 3.36 \\
2 & 3.72 & 5.33 & 0.70 & 3.73 \\
3 & 4.44 & 5.45 & 1.15 & 5.93 \\
4 & 4.60 & 6.18 & 1.15 & 7.11 \\
5 & 5.13 & 6.20 & 1.15 & 7.14 \\
6 & 5.16 & 6.48 & 1.15 & 7.45 \\
7 & 4.95 & 5.41 & 1.15 & 6.23 \\
8 & 4.76 & 5.73 & 0.9 & 5.56 \\
9 & 5.28 & 6.96 & 0.9 & 6.26 \\
10 & 5.38 & 6.96 & 0.9 & 6.26 \\
11 & 5.08 & 6.57 & 0.9 & 5.91 \\
12 & 5.03 & 6.17 & 0.9 & 5.55 \\
13 & 4.77 & 6.63 & 0.75 & 5.23 \\
14 & 3.39 & 5.91 & 0.75 & 4.43 \\
Avg. rate & 4.59 & & & 5.73 \\
Sum & 449.85 & & & 561.54 \\
\hline & & & & \\
\hline
\end{tabular}

(IIS) and (ICS) treatments were 481.92 and $660.17 \mathrm{~mm}$ $\left(4,819.2\right.$ and $\left.6,601.7 \mathrm{~m}^{3} / \mathrm{ha}\right)$, respectively. These amounts were less than the amount of irrigation water practiced by the framers in the area. The total volume of water normally applied for irrigating tomato in Riyadh area was 7,202 $\mathrm{m}^{3} /$ ha using drip irrigation method. The IIS was $27 \%$ less than that applied for the ICS treatment, which was less than that amount applied normally by farmers in Riyadh regions.

The weekly accumulative irrigation water added $\left(D_{\mathrm{g}}\right)$ to tomato throughout crop growing period for both Systems were presented in Fig. 5. The analysis of these two curves points out that their values were close only in the initial development stages and extremely spreading out gradually along the season.

\section{Statically analysis of yield}

Wheat crop data were statistically analyzed and the least significant differences (LSD) test was used to compare means at the 5\% level. These values under two water treatments were shown in Table 7 . The agronomical data of
Fig. 4 Weekly $\mathrm{ET}_{\mathrm{c}}$ for tomato vs. crop growth period for IIS and ICS treatments

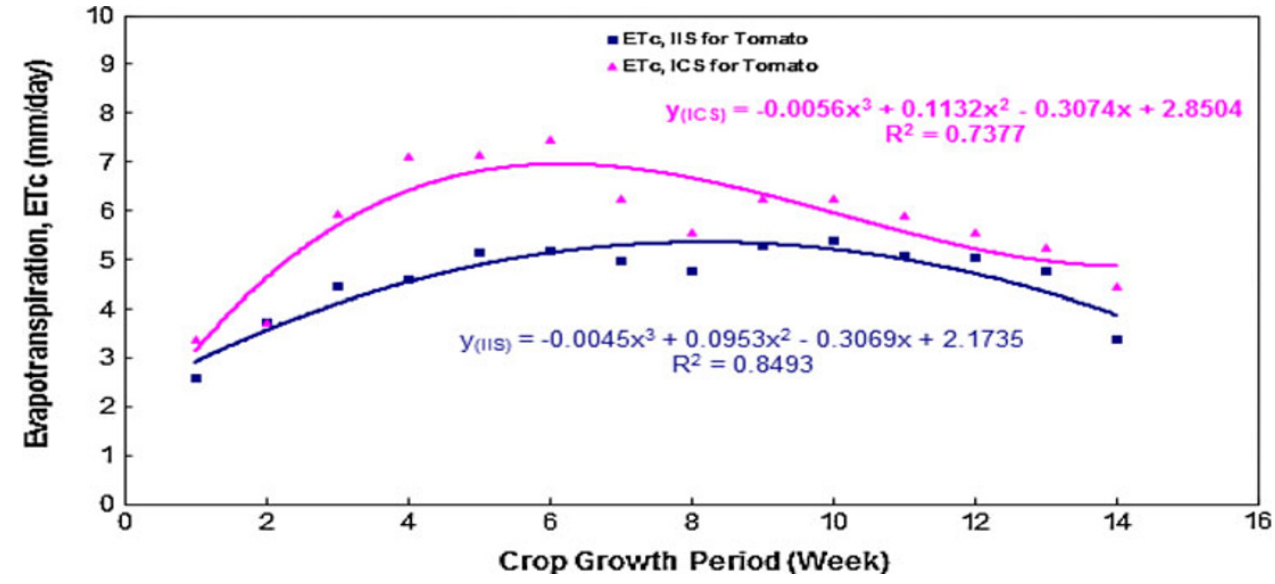


Table 5 Irrigation water added $\left(D_{\mathrm{g}}\right)$ to tomato crop for IIS treatments

\begin{tabular}{lccc}
\hline $\begin{array}{l}\text { Growing } \\
\text { period (week) }\end{array}$ & $\begin{array}{l}\text { Water } \\
\text { added }\left(\mathrm{m}^{3}\right)\end{array}$ & $\begin{array}{l}\text { Irrigation depth } \\
\left(D_{\mathrm{g}}\right)(\mathrm{mm})\end{array}$ & $\begin{array}{l}\text { Accumulative depth } \\
\left(D_{\mathrm{g}}\right) \mathrm{c}(\mathrm{mm})\end{array}$ \\
\hline 1 & 0.97 & 19.52 & 19.52 \\
2 & 0.68 & 13.54 & 33.06 \\
3 & 1.06 & 21.32 & 54.38 \\
4 & 1.64 & 32.62 & 87.00 \\
5 & 1.46 & 29.20 & 116.20 \\
6 & 1.82 & 36.31 & 152.51 \\
7 & 1.72 & 34.44 & 186.95 \\
8 & 1.99 & 39.70 & 226.65 \\
9 & 2.08 & 41.70 & 268.35 \\
10 & 2.09 & 41.84 & 310.19 \\
11 & 2.14 & 42.87 & 353.06 \\
12 & 2.35 & 46.91 & 399.97 \\
13 & 3.00 & 60.07 & 460.04 \\
14 & 1.10 & 21.88 & 481.92 \\
Sum & 24.10 & 481.92 & $3,149.8$ \\
\hline
\end{tabular}

Table 6 Irrigation water added $\left(D_{\mathrm{g}}\right)$ to tomato crop for ICS treatment

\begin{tabular}{llcc}
\hline $\begin{array}{l}\text { Growing } \\
\text { period (week) }\end{array}$ & $\begin{array}{l}\text { Water } \\
\text { added }\left(\mathrm{m}^{3}\right)\end{array}$ & $\begin{array}{l}\text { Irrigation depth } \\
\left(D_{\mathrm{g}}\right)(\mathrm{mm})\end{array}$ & $\begin{array}{l}\text { Accumulative depth } \\
\left(D_{\mathrm{g}}\right) \mathrm{t}(\mathrm{mm})\end{array}$ \\
\hline 1 & 1.71 & 34.16 & 34.16 \\
2 & 1.60 & 32.03 & 66.19 \\
3 & 2.33 & 46.61 & 112.80 \\
4 & 2.53 & 50.54 & 163.34 \\
5 & 2.66 & 53.16 & 216.50 \\
6 & 2.94 & 58.78 & 275.28 \\
7 & 3.03 & 60.54 & 335.82 \\
8 & 2.98 & 59.48 & 395.30 \\
9 & 2.46 & 49.22 & 444.52 \\
10 & 2.65 & 52.82 & 497.34 \\
11 & 2.39 & 47.93 & 545.27 \\
12 & 1.69 & 33.74 & 579.01 \\
13 & 2.80 & 55.91 & 634.92 \\
14 & 1.26 & 25.25 & 660.17 \\
Sum & 33.03 & 660.17 & $4,960.62$ \\
\hline
\end{tabular}

the water treatment revealed significant variation in grain yield, biological yield, harvest index 1,000 kernel weight, Spike length, plant height and WUE. The average grain yield was 6.10 and 5.07 ton/ha for Control and Intelligent systems treatments, respectively. The average biological yield was 16.02 and 13.35 ton/ha for the same treatments, respectively. Grain yield in intelligent irrigation technique (IIS) was $17 \%$ less when compared to the control treatment (ICS). In the aforementioned table, the harvest index, 1,000-kernel weight, and plant height the highest values also obtained for control technique were given. In addition, WUE had the highest values in IIS treatment $\left(1.31 \mathrm{~kg} / \mathrm{m}^{3}\right)$ compared to the ICS treatment $\left(0.89 \mathrm{~kg} / \mathrm{m}^{3}\right)$ as shown in Table 7.

A summary of the vegetative growth, fruit and Yield characters for tomato plants growing in IIS and ICS treatments were presented in Table 8. The agronomical data of both water treatments showed signs of good growth during the growing season. The average tomato yield was 39.2 and 34.4 ton/ha for IIS and ICS water treatments, respectively. Comparing the tomato yield between IIS and ICS treatments, the variation was $14.5 \%$. The reason the IIS resulting in greater yield than ICS could be attributed to the variation of amount of water added to the two treatments and the timing of irrigation. Comparing the yield of tomato obtained with the average in the Riyadh region, we found that the quantity obtained was in the upper limit of the overall output.

\section{Conclusions}

The study was conducted with sprinkler and drip irrigation systems, which were commonly used with these two types of crops. The intelligent ICS has been successfully chosen, implemented and functioned in the field. The system configuration was changed to meet the water requirements
Fig. 5 Weekly cumulative irrigation water added $\left(D_{\mathrm{g}}\right)$ to tomato crop during the growth period for IIS and ICS treatments

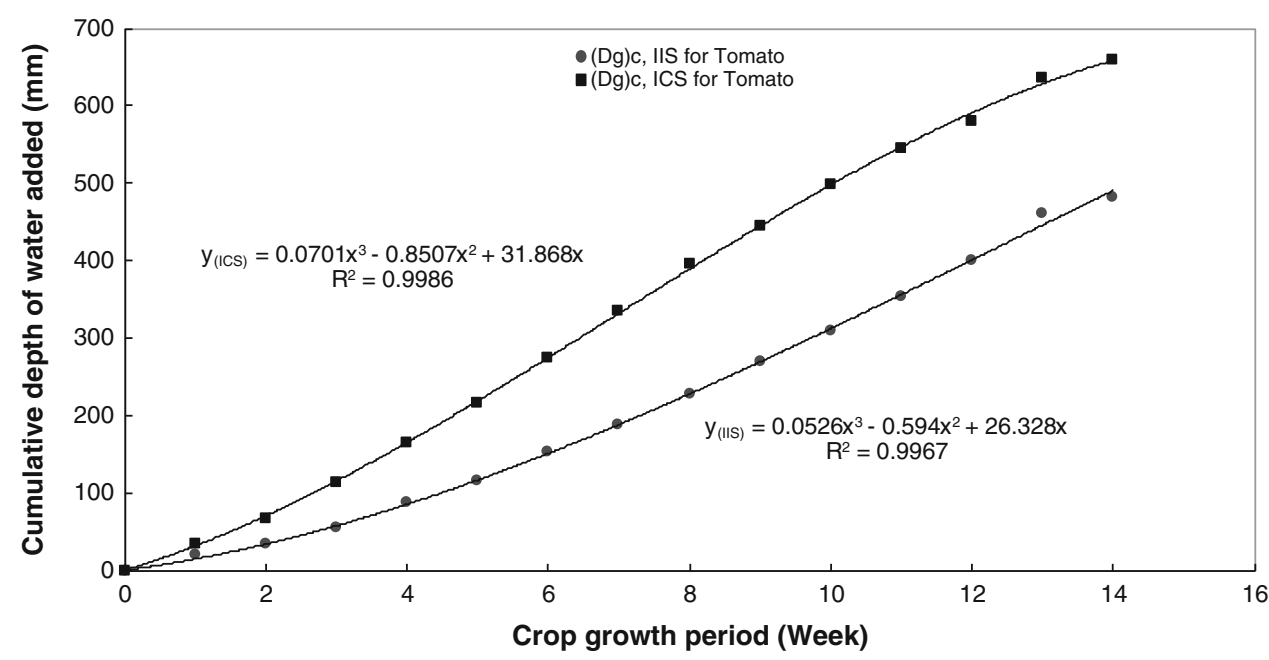

Crop growth period (Week) 
Table 7 Statistical analyses of wheat crop data

\begin{tabular}{llllllll}
\hline Treatment & $\begin{array}{l}\text { GY } \\
\text { (ton/ } \\
\text { ha) }\end{array}$ & $\begin{array}{l}\text { BY } \\
\text { (ton/ } \\
\text { ha) }\end{array}$ & $\begin{array}{l}\text { HI } \\
(\%)\end{array}$ & $\begin{array}{l}\text { KW } \\
(\mathrm{gm})\end{array}$ & $\begin{array}{l}\text { PH } \\
(\mathrm{cm})\end{array}$ & $\begin{array}{l}\text { SPL } \\
(\mathrm{cm})\end{array}$ & $\begin{array}{l}\text { WUE } \\
\left(\mathrm{kg} / \mathrm{m}^{3}\right)\end{array}$ \\
\hline IIS & $5.07^{\mathrm{b}}$ & $13.35^{\mathrm{b}}$ & 0.38 & $39.12^{\mathrm{b}}$ & $49.50^{\mathrm{b}}$ & 9.5 & $1.31^{\mathrm{a}}$ \\
ICS & $6.10^{\mathrm{a}}$ & $16.02^{\mathrm{a}}$ & 0.38 & $47.68^{\mathrm{a}}$ & $66.25^{\mathrm{a}}$ & 10.0 & $0.89^{\mathrm{b}}$ \\
LSD & 0.85 & 2.58 & $\mathrm{NS}$ & 5.21 & 3.18 & $\mathrm{NS}$ & 0.17 \\
$(0.05)$ & & & & & & & \\
\hline
\end{tabular}

$G Y$ grain yield, $S P L$ spike length, $B Y$ biological yield, $P H$ plant height, $H I$ harvest index, $K w 1,000$ kernel weight, $W U E$ water-use efficiency, $N S$ not Significant

a Significant at 0.05 level

b Significant at 0.05 level

Table 8 Vegetative growth, fruit and yield characters for tomato plants

\begin{tabular}{lll}
\hline Characters & IIS treatment & ICS treatment \\
\hline Plant height $(\mathrm{cm})$ & 44 & 39 \\
Number of branches & 6 & 5 \\
Fruit length $(\mathrm{cm})$ & 6.3 & 5.7 \\
Fruit diameter $(\mathrm{cm})$ & 4.6 & 4.8 \\
Fruit shape index (length/diameter) & 1.37 & 1.2 \\
Average fruit weight $(\mathrm{g})$ & 95.0 & 93.0 \\
Early yield $\left(\mathrm{kg} / \mathrm{m}^{2}\right)^{\mathrm{a}}$ & 2.36 & 2.40 \\
Early yield $(\mathrm{ton} / \mathrm{ha})$ & 23.6 & 24.0 \\
Total yield $\left(\mathrm{kg} / \mathrm{m}^{2}\right)$ & 3.92 & 3.74 \\
Total yield $(\mathrm{ton} / \mathrm{ha})$ & 39.2 & 34.4 \\
\hline
\end{tabular}

a The first fife harvests

according to the crop growth stages. There were some options to choose for supplying more water or less according to the needs of plants. In this study, the system was preset to operate with $80 \%$ of ET. The intelligent irrigation system along with the controllers works adequately and in a very accurate manner. This system showed its ability to provide more water for irrigation and has a potential for saving more water compared to irrigation scheduling based on ET measurements. All of the technologies tested (IIS) managed to reduce water application compared to the ICS and ET controllers resulted in water savings ranging from 18 to $27 \%$. Overall, the proper installation and set-up of each of the technologies tested here was an important factor in determining the effectiveness to which each system could reduce water application.

Acknowledgments The authors wish to thank The National Plan for Sciences and Technology (King Saud University in cooperation with King Abdul-Aziz City for Sciences and Technology) for providing funds to undertake this work through Grant No. 08-WAT327-2.
Open Access This article is distributed under the terms of the Creative Commons Attribution License which permits any use, distribution and reproduction in any medium, provided the original author(s) and source are credited.

\section{References}

Allen RG, Pereira LS, Raes D, Smith M (1998) Crop evapotranspiration guidelines for computing crop water requirements. FAO Irrigation and Drainage Paper No 56, p 301

American Society of Agricultural and Biological Engineers (ASABE) Standard S436.1 (2007) Test procedure for determining the uniformity of water distribution of center pivot and lateral move irrigation machines equipped with spray or sprinkler nozzles. ASABE, St. Joseph

Capraro F, Schugurensky C, Vita F, Tosetti S, Lage A, Patiño D (2008) Intelligent irrigation in grapevines: a way to obtain different wine characteristics. 17th FAC World Congress, Seoul, Korea.

Colin A, Whitford YD (1996) Intelligent irrigation (Booklet). Cohort International Pty Ltd, Australia

Dassanayake DK, Dassanayake H, Malano GM, Dunn Douglas P, Langford J (2009) Water saving through smarter irrigation in Australian dairy farming: use of intelligent irrigation controller and wireless sensor network. 18th World IMACS/MODSIM Congress, Cairns, Australia, pp 4409-4417

Iserman R, Lachmann K, Matko D (1992) Adaptive control systems. Prentice Hall, London

Kuo BC (1995) Automatic control systems, 7th edn. Prentice Hall, London

Lozano D, Mateos L (2007) Usefulness and limitations of decision support systems for improving irrigation scheme management. J. Agric Water Manage 95(4):409-418

McCready MS, Dukes MD, Miller GL (2009) Water conservation potential of smart irrigation controllers on St Augustine grass. J Agric Water Manage 96:1623-1632

Mendez-Barroso LA, Payan JG, Vivoni ER (2008) Quantifying water stress on wheat using remote sensing in the Yaqui Valley, Sonora, Mexico. Agric Water Manage 95(6):725-736

Merriam JL, Kelle RJ (1978) Farm irrigation system evaluation: a guide for management. Utah State University, Logan

Michael D, Dukes MD (2008) Water conservation potential of smart irrigation controllers. In: 5th National decennial irrigation conference proceedings, Phoenix convention center, Phoenix, AZ, USA IRR10-9520. ASABE 2950 Niles Road, St. Joseph, MI 49085

Muñoz-Carpena R, Dukes MD (2005) Automatic irrigation based on soil moisture for vegetable crops IFAS extension. University of Florida

Muñoz-Carpena R, Li Y, Olczyk T (2003) Alternatives for low cost soil moisture monitoring devices for vegetable production in the south Miami-Dade County agricultural area. Fact Sheet ABE 333 of the Department of Agriculture and Biological Engineering, University of Florida

Nautiyal M, Grabow G, Miller G, Huffman RL (2010) Evaluation of two smart irrigation technologies in Cary, North Carolina. An ASABE Meeting Presentation, Paper Number: 1009581. Presentation at the ASABE Annual International Meeting, David L. Lawrence Convention Center, Pittsburgh, Pennsylvania.

Norum MN, Adhikari D (2009) Smart irrigation system controllers. In: 7th World Congress on computers in agriculture conference proceedings, Reno, Nevada. ASABE, St. Joseph, Michigan 
Playán E, Mateos L (2006) Modernization and optimization of irrigation systems to increase water productivity. Agric Water Manage 80:100-116

Smajstrla AG, Locascio SJ (1997) Tensiometer-controlled, drip scheduling of tomato. Appl Eng Agric 12(3):315-319

Wolter HW, Burt CM (1996) Concepts for irrigation system modernization. In: Proceedings of the expert consultation on modernization of irrigation schemes: past experiences and future options, Bangkok, Thailand, 26-29 Nov, Food and Agricultural Organization of the United Nations

Zazueta FS, Smajstrla A, Clark GA (1994) Irrigation system controllers. Sheet SS-AGE-22. Department of Agricultural and Biological Engineering, Florida Cooperative Extension Service, Institute of Food and Agriculture sciences, University of Florida 